Opinion

\title{
The Era of Sustainability: Promises, Pitfalls and Prospects for Sustainable Buildings and the Built Environment
}

\author{
Emilia Conte
}

DICATECh, Polytechnic University of Bari, 70125 Bari, Italy; emilia.conte@poliba.it; Tel.: +39-080-596-3466

Received: 7 May 2018; Accepted: 17 June 2018; Published: 20 June 2018

\begin{abstract}
Following 25 years of efforts in the field, the author discusses the situation of the construction sector by reflecting on the 3Ps of the era of sustainability: the promises of sustainability; the pitfalls in the interpretation of sustainability for construction; the prospects for sustainable buildings and the built environment in the future. The paper is organized into five sections. The first section introduces the emergence of sustainable construction, its promises and challenges for architects and engineers. The second section considers how sustainability has been interpreted in practice in construction, i.e., primarily through the process of greening buildings and the built environment. The third section describes the main pitfalls that such interpretation has determined, including the role played by evaluation and assessment systems for sustainable buildings. The fourth section examines prospective paths to overcoming such pitfalls, with particular concerns for new professionalisms and the ensuing role for higher education. The fifth section concludes by supporting the idea that the era of sustainability is still necessary, if sustainability itself becomes a sort of 'container concept' of all that is necessary for long-lasting natural and human life on Earth.
\end{abstract}

Keywords: sustainable development; sustainable building; built environment; era of sustainability; greening process

\section{Introduction: Promises of Sustainable Construction}

The definition of sustainable development given in the Bruntland report in 1987 [1] can be considered the starting point of a new era: the era of sustainability. Sustainable development was not a new concept, but the cited definition marked the urgency of a new awareness because it highlighted the responsibility of humans for their descendants. The natural environment emerged as a finite resource posing certain limits to development. Therefore, a systems approach to sustainability is considered necessary, interconnecting the goals of three systems, environment, society and economy, to produce the general goal of sustainable development [2]. The potential of such definition is great, because it implies an ethical concern [3]. The adjective 'sustainable' has a broad meaning that includes many characteristics of development, even beyond the environment-society-economy recalled by the Bruntland report [4]. Several scholars of different disciplines have studied and proposed a conceptualization of sustainable development originating in a vast set of meanings and contents for sustainability (see, for example, [5]). This shows on the one hand the vagueness of the concept [6] and on the other hand its interest across disciplines [7]. Since 1987, sustainability has become the distinctive feature of any discourse and sustainable development the only possible way to operate in any field. It should be pointed out here that for some researchers, sustainability and sustainable development are interchangeable words [8], while for the author, sustainability better explains the conceptual level and sustainable development the operational level of development. 
Subsequently, after thirty years, we are immersed in sustainable development policies and implementations, but whether it is succeeding or not is questionable [9]. Recent studies confirm that the present state human development and its trend is not compatible with the carrying capacity of Earth [10], and there is increasing evidence that human activities influence climate change [11]. Socio-economic analyses testify that different forms of inequality and lack of equity still exist [12]. Has sustainability been a misleading concept and sustainable development an insufficient effort? Should one consider the era of sustainability concluded in favor of other forms of development? It seems that the word sustainability, as well as the related concept, is no longer trendy, while for example resilience [13] or smartness [14] are increasingly being used to represent the new targets of development. The author believes that promises of sustainability are still there, but pitfalls in sustainable development have determined unsatisfying results, and in some ways have generated the need for imagining different forms, and content, of development. The author reaffirms the need to continue the era of sustainability, recognizing its prospects in the field of sustainable buildings and the built environment.

A milestone with regard to sustainability in the construction sector can be considered the definition of the objective of sustainable construction as "the creation and responsible management of a healthy built environment based on resource efficient and ecological principles" given by Prof. Charles J. Kibert in 1994 during the Final Session of the First International Conference of CIB TG 16 on Sustainable Construction, Tampa, Florida. The ecological approach to designing the built environment, in search of harmony with nature and treating built artefacts as an organism of nature, was not new at that time, being rooted in the fundamental works of scholars of the 1960s, 1970s and beyond [15] (p. 24). However, it is at the 1994 Conference that the adjective 'sustainable' is, for the first time, associated with construction. Kibert [16], in his paper at that Conference, recognizes sustainability criteria versus traditional criteria characterizing buildings materials, products and systems. He establishes six principles for sustainable construction: conserve, reuse, renew/recycle, protect nature, non-toxics, quality. He conceptualizes a model that relates these principles to resources and time, where time corresponds to phases of the construction process. The main goal is to support the construction industry in its 'new' responsibility for sustainable development at "the start of a new era that has sustainability as perhaps the major objective in creating the built environment" [16] (p. 3).

Sustainability has begun to be included in theory and practice related to the construction sector, by virtue of the essential contribution given by the International Council for Research and Innovation in Building and Construction (CIB) [17]. Sustainable construction emerges as the means by which it is possible to create and responsibly manage a built environment able to ensure the healthiness of inhabitants and, at the same time, of the natural environment, by saving its resources and controlling its pollution. There are three factors to highlight: construction activities have a responsibility for sustainable development (the means); the sustainable built environment is the objective of these activities (the goal); the preservation of the natural environment is the basis of these activities (the starting point). Environment (starting point), society (goal) and economy (the means) are related in the construction sector; therefore, it has become a privileged field to test sustainability in practice through sustainable development of the built environment. Sustainable construction symbolizes the great, all-embracing, promise to contribute significantly to sustainable development, locally and globally, improving the built environment while protecting the natural environment- the way to establish a balance between human life and nature without one prevailing over the other and, thus, their long-lasting coexistence. Sustainable buildings and sustainable development of the built environment become a mantra of sustainability.

However, what is defined in theory is often hard to apply, particularly in the absence of appropriate tools, as was the case of sustainability, whose governance processes were still to be discovered [18]. While, in the construction sector, the vision of sustainability appeared clear, knowing the 'new' premises and scope of the construction activities was not enough because there was a lack of know-how. The push towards sustainable development generated the need to sustainably orient 
the construction sector, but the definition by Kibert came before the construction actors had become ready to sustainably operate. It was useful to know why, what and where to operate sustainably, but how to do it in practice was complex [19]. This situation characterized all sectors and fields of implementation and was determined not so much by the vagueness as by the novelty of the concept of sustainability and, consequently, the absence of a structured and consolidated knowledge of it and its implementations.

Indeed, as in any other field, sustainability has strongly challenged actors of the sustainable construction process; considering interconnecting environment, economy and society, and interlinking generations of actions aimed at sustainable development of the built environment, is a complex activity for which involved actors are required to renovate their knowledge, competence and skills [20]. Among them, architects and engineers can be considered the most important protagonist in the process of making constructions sustainable because they: are producers, users, and the vehicle of knowledge; have not only specific but also overall competences; and possess the technological skills. Toward architects and engineers as designers and managers of the sustainable built environment, sustainability poses the major challenges of reinterpreting their socio-cultural role and remodeling their professionalism.

The author discusses, with these premises in the following sections, the situation of sustainability in construction, specifically of sustainable buildings and the built environment, based on personal experiences of research in the field and university teaching in architectural engineering for over twenty years.

\section{Sustainable Buildings and the Built Environment}

Since 1994, much progress has been made all over the world, and several examples are available of how sustainability of buildings and the built environment has been interpreted (see, for example, [21]). The key to understanding what unites these experiences is the greening process. The need to recover the environment from depletion of its non-renewable resources and combat increasing pollution has prevailed on the global goal of creating a built environment able to balance natural and human life. Reasons for this are several and interlaced, with energy policies among the most important [22]. Some essential elements that have supported the greening process of buildings and the built environment are described in the following.

First, the environment has been identified as the sick to be treated urgently; society and the economy cannot be developed in the absence of sufficient and healthy natural resources. The 1972 Meadows report [23] already indicated 'the limits to growth', highlighting that natural resources on Earth are exhaustible, as well as the absorption capacity of pollutants is limited. An environmental awareness began to spread, though at the same time some criticisms were raised [24]. The Bruntland report, as reported above, reaffirmed the limits to socio-economic development if not reinterpreted sustainably. The environmental awareness increased because the ethical concern for future generations was introduced [25]. Resource efficient and ecological principles invoked at the basis of sustainable development processes in the construction sector have become the goal of sustainable building design, reversing starting and final points of the implementations. The commitment has been the recovery of the natural environment, that is the greening process, rather than the creation and management of a sustainable built environment, thus demonstrating the care for the environment so impoverished over time but also overlooking the opportunity to establish a synergy of development between human and natural life.

The greening process of buildings and the built environment was easier to face than trying to discover new forms of development after all. It was the way to give certain and simple answers to uncertain and complex demands posed by sustainability. It allowed using available knowledge and technology rather than producing new knowledge of, and technology for, sustainability implementations. Therefore, the greening of buildings and the built environment was an expression of the usual way of thinking and operating, which had characterized the previous decades; 
the representation of a worldview mainly based on reductionism [26] and the power of technology [27]. Through reductionism, it is possible to represent reality as a set of separate parts, and this allows dealing with real problems in a simpler manner than considering their interconnectedness. Via recognizing the great power of technology, it is possible to shift the solution to an operational level rather than trying to give answers on a theoretical, and then ethical, base. Sustainability of buildings and the built environment has been 'reduced' to the greening of them to face and solve the problem of the impoverished and polluted environment by means of technology used at several levels-from design to management, from construction to demolition, from production to operation-and by all the actors involved in sustainable development: politicians, architects and engineers, investors, contractors, researchers, producers, citizens. Greening has allowed us to elude the vagueness and complexity inherent in the concept of sustainability, as well as the challenges of it, guaranteeing the actors of the building process to persevere in using habitual knowledge, design approaches and working routines.

Though the new target of building activities, greening, is aimed at recovering the environment, what really emerges is the human-centered vision of life on Earth [28]; humans have created such a degraded situation and humans must remedy it through technology, which favorably corresponds to taking responsibility but also unfavorably shows faith in technological improvements as the way to escape rather than in revising human behaviors and the whole vision of development, eventually supported by technology. Therefore, responsibilities are taken in relation to the present status of the environment more than toward future generations [29]. This reveals an approach on the operational level definable as 'here and now' rather than 'anywhere and forever', which is unable to grasp the real chance offered by sustainability to think and practice a long-lasting development.

One more element deserves attention in this scenario, and it is the interpretation of the built environment used in the greening process, as above described. The environmental goal, together with the reductionist approach and the faith in technology, has determined a prevalent interpretation of it as a sum of man-made artefacts [30] to be greened as much as possible to guarantee the sustainable development of a place. The idea is that adding sustainable buildings to sustainable infrastructures can make sustainable neighborhoods, towns and cities. Yet again, it is a vision that simplifies the action making it possible to face it with the usual knowledge and tools rather than considering a systemic vision more able to represent the complexity of the built environment and a sustainable development of it based on multiple factors interconnected and evolving during time.

These key elements have guided the design and management of sustainable buildings primarily toward their greening. Going through the history of sustainable buildings of the last 25 years, some focal steps can be summarized (Figure 1).

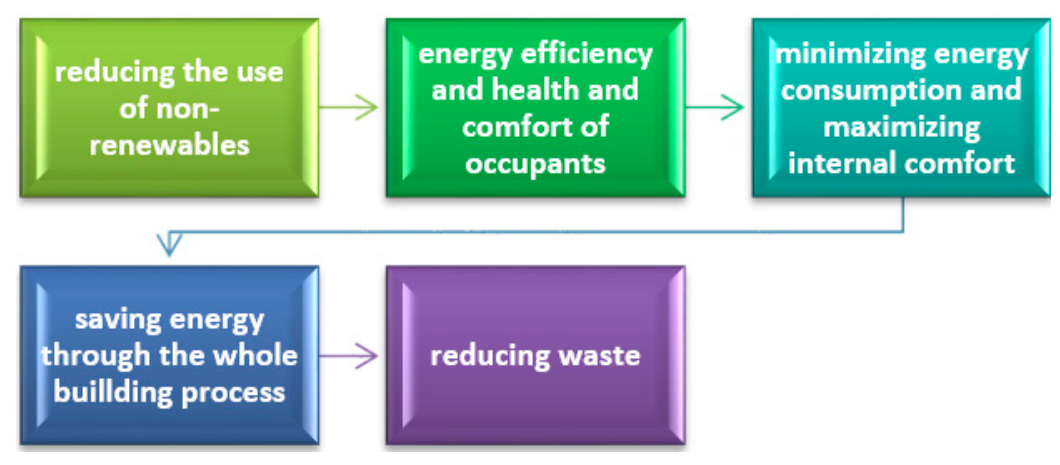

Figure 1. Improving the target of the greening process in building design over the years.

The energy crisis of the 1970s [31] oriented us to reduce energy consumption, at that time mainly based on oil. This meant work toward energy conservation at the building level [32], principally through heating and HVAC systems in general. Regarding existing buildings, a large applied solution was to add an insulation layer to walls, ground floors and roofs; for new construction, a revival of 
principles of bioclimatic architecture grew up reclaiming attention to the local construction traditions as well as the exploitation of natural phenomena, like thermal inertia, greenhouse effect, natural convection, and chimney effect, in building components. The introduction of sustainability in the construction sector, signifying an environmental crisis that could jeopardize the health and comfort of humans, emphasized these trends, focusing attention on the building envelope on the one side to insulate it at a maximum level and, on the other side, to design its passive behavior so to use renewable resources, particularly the sun and the wind. Solar energy capture, thermal masses, and light transparency, were introduced in the building envelope components to reduce the heating demand; natural ventilation was introduced into the indoor environment to reduce cooling demand. Concurrently, increased attention was devoted to solar active systems like solar and PV panels to supply the residual demand for the use in buildings. Therefore, reducing the use of non-renewables was the essential target in the design of both new and existing buildings.

Learning from this first step of commitment, new elements deserved attention in the design of buildings which can be synthetized as moisture control and efficiency of energy installations. The introduction of an insulation layer into the envelope of existing buildings as well as the highly insulated and air-tight building envelope of new constructions can generate the presence of moisture inside the envelope or in the indoor environment, creating degradation of building materials and components and decreasing the occupants' comfort [33]. Sometimes the renovation works on existing buildings have been shown to reduce the performance of the building rather than enhancing it. Moreover, reducing the use of non-renewables by means of a well-insulated building envelope or passive/bioclimatic solutions is not substantial if energy installations are not efficient; and vice versa, efficient energy installations, even those using solar and PV panels, are not sufficient if the building envelope is not designed to decrease the energy demand. Therefore, two main targets characterized new and existing building design: one is the energy efficiency of the integrated system composed by the building envelope and the HVAC installation and the other is the health and comfort of occupants.

Recognizing that energy efficiency depends on the integrated functioning of the building envelope with the HVAC installation, and relating it to the well-being of people, stimulated the search for solutions able to manage these aspects optimizing the building performances; the principal interpretation of this has been automation. It was not a new concept in building but progresses in information and communication technologies allowed for the reconsidering of the potential of building automation in contributing to sustainability [34] through the control of energy consumption, indoor air quality, and physical-physiological parameters of occupants. The use of automation has been a real aid in combating waste of energy and, at the same time, a way to adapt the performance of the building to the external environment and the user, making its behavior responsive and dynamic. Therefore, minimizing energy consumption and maximizing internal comfort in any condition of use of the building pushed forward the targets of sustainable building design.

The approach to sustainable building design was mainly based on controlling the use of non-renewables and the effects on the environment. This determined a consequent step, which was to give attention to the time related to building, because energy sources are drawn upon, and environmental pollution is generated, throughout the whole building process. Studies based on the life-cycle approach were initiated to be applied to buildings. However, buildings are 'objects' very different from other objects of use and are very much differentiated one from the other, thus making it complex to apply such an approach [35]. Creating databases on building materials and components useful to apply the life-cycle approach has been addressed by many scholars, as well as the need for considering different production processes in different countries. Nevertheless, the life-cycle approach has been affirmed in the building field because its goal to calculate environmental impacts and elements dangerous for the healthiness of inhabitants and construction workers well represents the objective of sustainable construction as "the creation and responsible management of a healthy built environment based on resource efficient and ecological principles". Although the assessment based on the life-cycle has limitations [36], life-cycle thinking has helped to bring into the project the 
necessary attention to the entire building process. Therefore, the prominent target for new and existing building design was to extend the energy saving and efficiency to other phases of the building process before and after the construction or refurbishment of a building, thus also determining the healthiness of the built environment.

The need to save energy and reduce waste in the building field, highlighted by the life-cycle approach, has led to promote into building design the use of low-impact materials [37], such as natural, local, recycled/recyclable materials. Natural materials need less energy in their production; local materials need less energy for their transportation; recycled/recyclable materials reduce the quantity of materials to landfill. Such attention to building materials has generated two kinds of improvements: a renewed interest in old construction materials, for example wood and its derivatives, and the creation of new products for buildings, for example roofing membrane by recycled PVC materials. The building industry that was already solicited for insulation materials with good environmental performance and low environmental impact [38], was then further pushed by this request for low embodied energy materials and recycled/recyclable materials to be used throughout buildings, not only for insulation. Consequently, the environmental certification of building materials has increasingly become a proof of the energy requirements of production or the percentage of recycled content.

Presently, this orientation is not only about materials, but also about components and products used in the building, which, if properly chosen from the initial design phase, can significantly contribute to the reduction of construction waste [39]. However, what is notable is the reason for this commitment to further lessen the environmental load by means of energy saving and waste reduction, which has more recently integrated the target of designing sustainable buildings, both new and existing.

\section{The Greening Process and Its Pitfalls}

The greening process of buildings and the built environment has been supported by a favorable context of action created by the legislation, often accompanied by incentives, and the propagation of evaluation and assessment systems for sustainable buildings. These two evolving scenarios have grown in parallel thus strengthening each other.

The European level, for example, signaled the starting interest of the EU for building regulation in the 1990s. This happened because the question of climate change arose, and buildings were recognized as significant contributors to the energy demand. The goal of the EU was the reduction of the use of fossil fuels. Still in line with European initiatives versus climate change [40] regarding reducing carbon emissions and impacts of climate change, in 2002 the EU adopted the first Energy Performance Building Directive (EPBD) [41], indicating to European countries that requirements of energy efficiency had to be included in building regulations at national levels. Due to meagre results in the first years of its application, the EPBD was reworked and a new Directive was adopted in 2010 [42]. Since then, the EPBD together with the Energy Efficiency Directive adopted in 2012 [43] have created the main legislative scenario for energy use in buildings, aiming at reducing their energy consumption by improving their energy efficiency toward nearly-zero energy buildings by 2020. Energy performance certifications, inspection rules for HVAC installations, energy efficiency requirements also in case of renovation/retrofit works, and financial measures at national levels to improve energy efficiency of buildings, are the leading aspects of those directives that are applied in national legislation.

Soon after the definition of sustainable development, the Building Research Establishment (BRE, UK) launched its environmental assessment method, BREEAM, in 1990 to evaluate environmental performances of buildings [44]; hence, it was the initial sustainability assessment method for buildings. The pilot version of the Leadership in Energy and Environmental Design (LEED) rating system for new construction was launched by the Green Building Council of the United States (USGBC) in the late 1990s; then, in 2000, it evolved into the LEED Green Building Rating System [45]. Similarly, in the late 1990s, an international collaboration was established, the Green Building Challenge (GBC), to develop an assessment framework and the related Green Building 
Tool (GBTool) to evaluate building environmental performances. Following a period of validation, assessed buildings in different countries were presented at the Sustainable Building 2000 conference, in Maastricht, The Netherlands [46]. This was the first of a series of conferences known as SB [47] that, thereafter, have been seen as an international benchmark in the 'world' of sustainable buildings. Subsequently, the GBC Method and Tool evolved into the Sustainable Building Method and Tool (SBTool), currently available [48]. It is useful to highlight that while BREEAM and LEED were developed respectively in England and the USA, although their version for other countries was later developed, the GBC effort was based on international cooperation to develop a system usable by any country by adapting the international SBTool to local situations. Moreover, it is necessary to remark that several other evaluation and assessment systems of sustainable buildings were developed [49]; however, they are indicated mainly for the countries or states that developed them. Therefore, BREEAM, LEED, and SBTool, are considered here because they are the most widespread systems in the world. All of them base the assessment on evaluation categories and indicators, and the content of sustainability of a building is expressed by a score that derives from weights assigned to categories and indicators in the system; the sustainable performance of the building is then rated by a certification issued by the system. They are all voluntary systems, increasingly used to be competitive on the market, as is especially the case of BREEAM and LEED which are paid systems; SBTool is free, so some local governments have chosen this system and, in their legislations, they require SBTool certification of a certain level to grant incentives.

Even in the extreme synthesis used here, the scenarios sketched above allow for identifying some key elements characterizing the implementation of sustainable buildings since the 1990s: energy efficiency, building performances, rating systems. The energy efficiency goal confirms greening as the most important aspect in building design; environmental performances of buildings prove their green behavior; evaluation and assessment rating systems become a means to measure building performances. Conversely, it must be recognized that this situation has much improved the design and construction of environmentally friendly buildings. Many 'sustainable' buildings are good examples of a green behavior as well as they are highly rated by environmental assessment systems. Then again, it must be admitted that this way of operating implies risks which have not been discerned and avoided; first a misunderstanding of sustainability and then a delay in building new knowledge and professionalism aimed at sustainable development. Despite such great commitment to greening buildings, the expected contribution that the buildings had to give globally for reducing environmental loads did not occur, thus much is still necessary to do, as shown in Europe by strategies of future development including targets updated to 2030 and 2050 [50,51], for example.

Focusing on single buildings, their performances, and their environmental score showed to be the main pitfalls.

Impelled by the environmental requests of sustainability, all the actors of the building process focused on what it was possible to apply to the design and management of buildings based on their current knowledge and expertise and available techniques. Along this line, the performance approach was very productive because it gave them the precise objectives to pursue in their work, confirming the usual way of operating already in practice during the 1980s, and also supported by the legislation in force [52]. Therefore, designing for and measuring building performances became the main commitment of architects and engineers, who could also draw on assessment systems to corroborate their design choices. Although those systems were applied on a voluntary basis, they became how it was possible to grant a project not only a high score, thus representing a good or best practice, but also by incentives of various forms [53], like tax reduction and volumetric bonus included in the legislation on energy efficiency. Thus, a virtuous but also vicious circle has been established in which criteria and indicators of assessment have determined design choices that have oriented laws and incentives which, in turn, have indicated the necessary updating of the criteria and indicators of evaluation. Similarly, it happened to determine the performances of the building, in type and size, which have been fixed by the legislation, then implemented into the design and used in the indicators 
of assessment systems which, in turn, due to the weights assigned to them, have suggested updates to threshold values of building performances included in the legislation. This operating circle is virtuous because it has sensitized all the actors involved in the process, like the architects, engineers, legislators, producers of building materials and components, builders, clients; however, it is also vicious, because it has caused an increasing in-depth analysis of technical solutions to improve each type of building performance at the best score disregarding the overall vision necessary to design a building specifically for its sustainable behavior. Hence, at the scale of the building, sustainability has been considered merely a summation of separate green performances, preferably highly rated by assessment systems. This perspective has already been referred to as buildingcentric [54]; it clearly reflects the interpretation of the built environment as a sum of man-made artefacts to be greened as much as possible to guarantee the sustainable development of a place, as commented above. However, this vision is reductionist and does not grasp the potential of sustainability expressible beyond the scale of the building, through the multiple and dynamic interactions between all components of the built environment, natural, human, and man-made.

A building is not isolated from its context; even considering only its energy behavior, it is strictly related to its natural, man-made and human surroundings. The presence of green areas and the dynamics of local climate, the building density of the area and the traffic, the way in which occupants and inhabitants use it, largely influence its behavior, for example, and then its performances. This poses the issue of measuring performances not only at the design stage but also during the occupation phase [55]. However, it is not only a matter of understanding how performances of buildings change during the operation phase, it is a question of how the real building behavior affects and is affected by the other components constituting the built environment and how it can cooperate to its sustainable development.

Persisting in habitual ways of work, lacking a systemic vision and continuing a greening process focused on buildings and driven by performances, the actions of sustainable development of the built environment have been shown to produce short-term results and to be incapable of establishing a synergy of development between human and natural life; this is much less than it could have been if the challenge posed by sustainability had been grasped. Having seen the insufficient results shown by all the efforts made everywhere for sustainable development, for years now scholars have begun to wonder if those efforts are able effectively to oppose the course of the growth on Earth, which remains still unsustainable [29]. The main approaches to pursue sustainable development, such as the greening of buildings in the construction sector, are used to persevere in the current situation but resorting to different means, such as improvements in technology and efficiency [56]. Although important, the greening process is not enough as long as it produces a collection of discrete initiatives while, on the contrary, sustainability asks for shifting fundamental values, paradigms and worldviews to maintain the efforts in the long-term [57]. Specifically, habitual practices of building design have not been modified by the greening process, thus resulting as inadequate to overcome the short-term results [58].

\section{Prospective Paths}

We must, therefore, support the construction and use of worldviews and related building design practices that enable sustainable development to go beyond the limits illustrated. New professionalisms are required for this, and higher education plays an essential role. To discuss this issue, the author reports personal experiences as a university teacher and researcher in sustainable buildings since 1995, in the following section.

This experience confirms the overall scenario of action as described above; hence, some improvements can be distinguished in updating theory and practice of sustainability over the years (Figure 2). During the first phase, the focus was on the assembly of new knowledge about sustainability, by means of design choices, although it was not finalized to revise the building design process. The second phase structured the evolving knowledge about sustainability, both theoretical and technical, to influence the design 
process aiming at sustainable buildings as an entirety more than adding sustainable choices to a conventional design. Subsequently, in the third phase, the focus moved on to using a systemic approach in building design to improve the content of sustainability in buildings. During the fourth phase, principles of complexity and holism were introduced in theory to consider the building not as an isolated object in its context but rather as a constituent part of the built environment in relationships with all the other constituents [59].

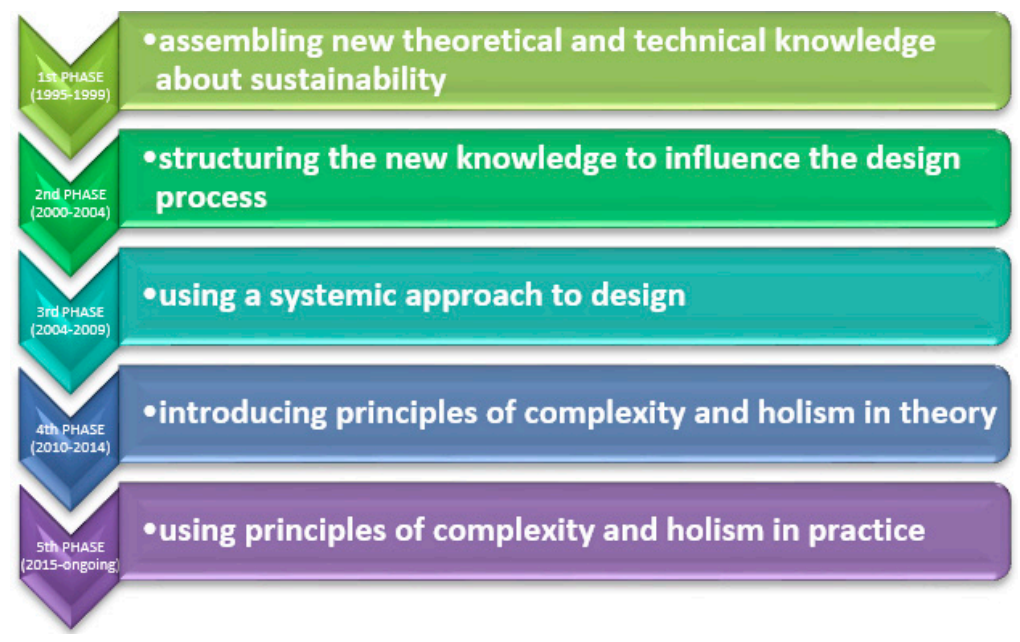

Figure 2. Advances in theory and practice of building design over the years according to the experience of the author (time intervals of five years).

What emerges from this experience is a growing awareness of the limited results produced by sustainable buildings that required a continuous raising of levels of theorizing, from applied knowledge, to design process, to the use of a systemic approach, to the introduction of complexity and holism principles on which to base building design to improve the sustainable development of the built environment. Recently, a major effort is devoted to the way in which these principles can be applied in practice to design sustainable buildings no longer as complicated systems based on performance, as they have been established so far, but as complex systems that participate in regenerating the built environment through their relationships with all the other complex systems in it, and giving it a capacity of adaptability and flexibility; thus, moving from theory to new practices of sustainability in construction beyond the greening process. For this purpose, in the author's opinion a forward perspective is offered, for example, by regenerative thinking [20]. Regeneration is the goal of a design process that assumes a worldview through which the natural and built environments are understood and dealt with as an integrated system in evolution and, therefore, considers their complex interrelationships [60]. A sustainable development based on the regenerative approach supports a partnership between humans and nature working together co-creatively [61]; it is a sustainable development able to generate and regenerate a built environment where human and natural system sustainably coevolve [62]. Some rationales can then be distinguished in the regenerative thinking; they support the idea that regenerative thinking can be a prospective path to practice to become more effective in the sustainable development of buildings and the built environment: (i) it is based on the whole system worldview which allows overcoming limitations of the reductionist approach so favoring the paradigm shift required by sustainability; (ii) it considers natural and human systems as a whole entity whose evolution is ensured by a development that considers relationships between nature and humans and aims to improve them with mutual benefits; (iii) it opposes the usual approach based on human actions to recover from environmental degradation in favor of an approach able to make the built environment self-maintaining in its functioning; (iv) it allows characterizing regenerative development and design as a coevolving effort in practice; (v) it recalls the importance of 'place' 
and that it is very significant to search for design solutions that are specific to a context and then a nature-built environment developing in suitable partnership [20]. Assuming the regenerative perspective, the sustainable development of the built environment becomes a process capable to redefine itself over time, thus posing open questions on the theoretical and the operational level.

This challenges the knowledge, competence and skills of professionals, particularly architects and engineers, as introduced above. The many efforts made so far to implement sustainable development of the built environment, although they have proven to be not quite effective, have produced a vast knowledge that has been used to improve technology, products, simulation tools, assessment systems for buildings, and so forth. Much knowledge can also be acquired directly or indirectly from websites of dedicated portals, producers, professionals, schools and universities, technical associations, national and international institutions, and many more. Nevertheless, the vaster the knowledge, the higher the risk to miss the holistic vision. It becomes more difficult to manage the knowledge useful for a project; a risk even greater for young professionals not yet experts or for professionals not enough educated and trained on sustainability. They risk making choices for or approaching the design of sustainable buildings on the basis of what is most used or better promoted rather than cultivating a personal conscious approach and making appropriate design choices uniquely for the project they are developing. Thus, the concern is the falling back into the main pitfall of concentrating on individual parts rather than considering the building as a whole. To avoid this risk, it is essential to mature critical skills in learning and using knowledge through collaborative experiences among different expertise [59].

Moreover, architects and engineers have the responsibilities to improve the design process to go beyond the buildingcentric approach and the greening of buildings as the main activity for sustainable development of the built environment. It is necessary for this that they mature not only in usual competences in design and management of buildings, but also in 'transboundary competences' [63] that can allow them to search for and innovate building design and management practices considering the building as an 'entry point' [60] among others in the built environment rather than as an isolated object in it. Thus, it seems more likely to improve the understanding of the natural, human and man-made system as a complex system to be developed in a sustainable integrated manner. However, this requires architects and engineers to consider effects of design choices not only at the scale of the building but also at the scale of the context in which the building is situated to consider interactions between all kinds of components in the built environment. The performance-based way of operating so largely used in sustainable buildings needs to be reinterpreted to evaluate the sustainable or unsustainable behavior of the whole built environment system. Architects and engineers must be prepared to overcome the reductionist approach in favor of using principles of complexity and holism in their professional work.

According to the holistic vision of the built environment, it is fundamental to include the evolutionary perspective in designing and managing the sustainable development of the built environment, thus ensuring strategies and solutions aimed at long-term results. Considering the built environment as a dynamic evolving whole, it is possible to recognize and promote development processes able to self-maintain themselves over time. This possibility is not predetermined, rather it must be studied project by project in a specific place. Being suggested by regenerative thinking, the local dynamics established in a place are determinant for its sustainable development [64]; learning the history of the place is the basis for understanding local dynamics that represent the way in which nature, humans and man-made systems have interacted in generating a built environment able to express characteristics of adaptability and flexibility over time [30]. This learning activity is a new challenge for architects and engineers who must grasp the potentialities of a place that can become real capacities during the regenerative development process [65]. It is an activity that requires architects and engineers to acquire not only technical competences and skills, as usual, but also new abilities suitable for engaging a dialogue with inhabitants, since they are an important source of knowledge of 
the place and its history, as well as for discovering innovative paths of sustainable development of the built environment.

It emerges from this discourse, the importance of the education of architects and engineers to new professionalisms allowing them to create a more sustainable built environment. Although any form of learning and any level of education takes part in forming the person and the citizen [66], the higher education system plays a crucial role, in fact, it is in colleges and universities that students acquire the analytical skills and practical competences that can enable them to operate according to high expectations [67] and become not only competent but also responsible professionals. Sustainability issues have challenged the formation of architects and engineers to create and manage a sustainable built environment [68], thus universities have been committed to renewing their programs and activities in many ways to achieve this goal. Today, it has become necessary to improve this commitment so to escape from the pitfalls encountered so far. Some prospects to do it concern the use of the holistic approach in teaching sustainability together with a reinterpretation of the built environment as a complex interrelated whole, and the promotion of cooperation among professionals.

It is compelling to shift from the usual reductionist approach to the holistic one, for the aforementioned reasons. This shift must be promoted by teaching architects and engineers no longer to decompose a system, like the built environment, in separate parts to simplify its representation, analysis and evaluation, but rather to study it with all the complex interactions that form it; thus, students can improve their ability to gather the necessary knowledge and, consequently, the design process aimed at sustainability [59]. The problem-solving activity that characterizes the professionalism of architects and engineers assumes even more significance if they are taught and learn to respect the complexity of the real world. Following this, the universities can lead the paradigm shift required by sustainability, educating their students to use the holistic approach. However, a critical aspect of this commitment is moving from theory to practice, which is essential in the education of architects and engineers. A reinterpretation of the built environment accompanying the holistic approach can support this move to avoid the scale-centered vision generally used today when designing sustainable buildings. Efforts are needed, both on theoretical and practical levels, to create new models of the built environment respecting the complex interactions between its components and managing them in an integrated way (see, for example, [65]). These new models can help students to study, design, build and manage the built environment as a whole system even when dealing with a single object that, in this way, becomes just an 'entry point' in the whole. The way of operating based on performance as well as the evaluation and assessment systems rating sustainable performances can have a role in supporting the reinterpretation of the built environment provided that they become able to consider cross-scalar integrated performances [69]. This new scenario for educating architects and engineers requires a further commitment to train students to cooperate. The vast knowledge of sustainability and the multiple sources of its acquisition, the need to recompose that knowledge project by project, the necessity of a continual updating of technical competences, the skills related to deal with the built environment as a complex whole, require basing design solutions and implementations on the cooperation among several professionalisms. Designing as a team is quite usual nowadays, but cooperation goes farther because asks professionals to share approaches and methods, as well as languages of communication on the built environment, to benefit from the differing expertise in the search for original solutions for sustainable development that are unlikely to be discovered individually [59].

\section{Conclusions: The Era of Sustainability Continues}

Recognizing prospective lines of action to improve sustainable development processes of the built environment shows the significance of continuing the era of sustainability. The concept of sustainability has permeated all the human activities since the late 1980s stimulating theories and practices, favoring the diffusion of a new environmental awareness, challenging habitual approaches and behaviors, demanding a contribution from all the actors involved in sustainable development. The power intrinsic 
in the concept of sustainability rousing humankind by recalling it to its responsibilities is indispensable for the future of all forms of living on Earth and must be maintained to achieve effective results in practice. Thirty years of efforts in sustainable development represent a period too short to prove their effectiveness because a paradigm shift is required [70]. Sustainability represents a historic leap that has not yet been completed. Since sustainable development has been introduced in daily activities, we have an important opportunity to rebuild an ethical commitment to future generations and the Earth. However, we might have missed this opportunity by treating sustainable development rather naively and using the habitual modus operandi and tools, rather than building new paradigms and new visions of the world. This has generated a break of knowledge [30] and, consequently, the inability to escape the pitfalls implied in the development processes implemented in recent years producing scarce results.

To become aware of these results does not mean replacing sustainability with another target, rather it means committing to improving what we do, an effort in which we are involved at every level, theoretical, methodological and operational. Knowledge, competences and skills evolve and enhance, enriching the content of sustainability in doing so. The new characteristics of development, as the aforementioned resilience or smartness in the construction field, should not represent a substitute character for sustainable development, rather, they are characteristics to be considered complementary to sustainability [71], as has been in the case of regeneration which is seen as a higher level of sustainability than practiced so far [60]. The peculiarity of the concept of sustainability is to evolve, because nature and humans evolve and thus, so must the culture and technology from which the man-made artefacts derive. Accepting the dynamic character of a sustainable development, then one can think of sustainability as a 'container concept' that collects all the characteristics of such development, characteristics that change over time to exploit new knowledge and expertise, but always aiming at ensuring a long-lasting natural and human life on Earth. Therefore, we can have a regenerative [72] or resilient [73] or smart [74] sustainability, but it is still sustainability. Using sustainability as a 'container concept', its definition remains blurred to accommodate the changes in the characteristics of sustainable development over time and to evolve operational objectives to be achieved for each period.

We have considered sustainable development while separating sustainable from development for thirty years, that is, the focus was on development as the socio-economic aspect of the (human) growth trying to make it sustainable, that is attentive to depletion of the (natural) environment. It has been a way to act in practice, well accepted because it has allowed perpetrating the usual idea of and approach to growth. Additionally, it has been a missed opportunity at the theoretical-methodological level, as testified by the fact that this commitment has not solved environmental issues and has not even adequately promoted the socio-economic growth globally [75]. The author resumed the promises of sustainability in the construction sector in general, summarized how sustainable development has been mainly interpreted specifically for sustainable buildings and the built environment, highlighted the main pitfalls that this interpretation has determined, where the actors of the building process have been trapped, and outlines prospects to continue the path toward true sustainability (Figure 3).

Some elements of the discourse inevitably did not find space and others were not detailed in this excursus; nevertheless, the treated aspects help to support the idea that the era of sustainability continues, because even if there remain many open questions and things to do, there are promising prospects for improving our commitment and achievements. 


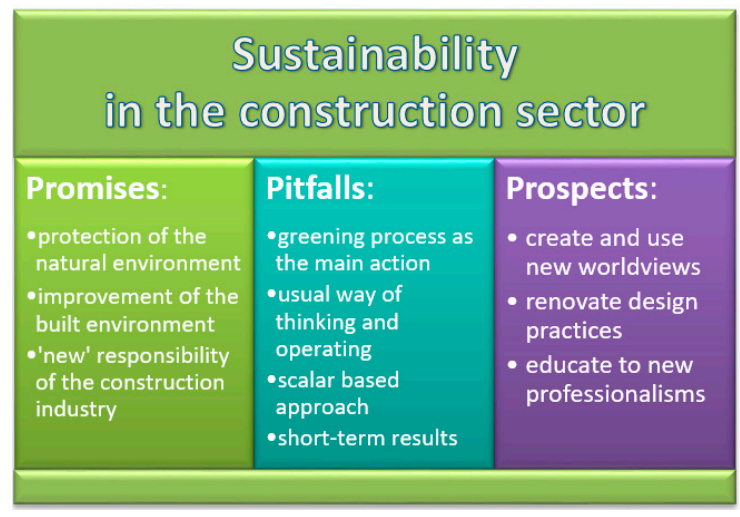

Figure 3. 3Ps at a glance; promises, pitfalls and prospects of the era of sustainability in the construction sector according to the opinion of the author.

Funding: This research received no external funding.

Conflicts of Interest: The author declares no conflict of interest.

\section{References}

1. WCED. Our Common Future: Report of the World Commission on Environment and Development. 1987. Available online: http:/ / www.un-documents.net/our-common-future.pdf (accessed on 25 April 2018).

2. Barbier, E.B.; Burgess, J.C. The Sustainable Development Goals and the Systems Approach to Sustainability. Economics 2017, 11, 1-22. [CrossRef]

3. Jabareen, Y. A new conceptual framework for sustainable development. Environ. Dev. Sustain. 2008, 10, 179-192. [CrossRef]

4. Burford, G.; Hoover, E.; Velasco, I.; Janoušková, S.; Jimenez, A.; Piggot, G.; Podger, D.; Harder, M.K. Bringing the "Missing Pillar" into Sustainable Development Goals: Towards Intersubjective Values-Based Indicators. Sustainability 2013, 5, 3035-3059. [CrossRef]

5. Sundsbø, A.O.; Runkle, B.R.K.; McMonagle, S.; Jantke, K.; Lottermoser, F.; Gottschick, M.; Häseler, S.; Rodriguez Lopez, J.M.; Scheele, M. One Metaphor-Several Meanings: An Interdisciplinary Approach to Sustainable Development. In Integrating Sustainability Thinking in Science and Engineering Curricula; Leal Filho, W., Azeiteiro, U., Caeiro, S., Alves, F., Eds.; Springer: Cham, Switzerland, 2015; pp. 197-213, ISBN 978-3-319-09473-1.

6. Pesqueux, Y. Sustainable development: A vague and ambiguous "theory". Soc. Bus. Rev. 2009, 4, $231-245$. [CrossRef]

7. Stock, P.; Burton, R.J.F. Defining Terms for Integrated (Multi-Inter-Trans-Disciplinary) Sustainability Research. Sustainability 2011, 3, 1090-1113. [CrossRef]

8. Waas, T.; Hugé, J.; Verbruggen, A.; Wright, T. Sustainable Development: A Bird's Eye View. Sustainability 2011, 3, 1637-1661. [CrossRef]

9. Engelman, R. Beyond Sustainababble. In Is Sustainability Still Possible? State of the World 2013; Worldwatch Institute, Island Press: Washington, DC, USA, 2013; pp. 3-16, ISBN 978-1-59726-415-0.

10. Motesharrei, S.; Rivas, J.; Kalnay, E.; Asrar, G.R.; Busalacchi, A.J.; Cahalan, R.F.; Cane, M.A.; Colwell, R.R.; Feng, K.; Franklin, R.S.; et al. Modeling sustainability: Population, inequality, consumption, and bidirectional coupling of the Earth and Human Systems. Natl. Sci. Rev. 2016, 3, 470-494. [CrossRef]

11. Stocker, T.F.; Qin, D.; Plattner, G.-K.; Alexander, L.V.; Allen, S.K.; Bindoff, N.L.; Bréon, F.-M.; Church, J.A.; Cubasch, U.; Emori, S.; et al. Technical Summary. In Climate Change 2013: The Physical Science Basis. Contribution of Working Group I to the Fifth Assessment Report of the Intergovernmental Panel on Climate Change; Stocker, T.F., Qin, D., Plattner, G.-K., Tignor, M., Allen, S.K., Boschung, J., Nauels, A., Xia, Y., Bex, V., Midgley, P.M., Eds.; Cambridge University Press: Cambridge, UK; New York, NY, USA, 2013; pp. 33-115. Available online: https://www.ipcc.ch/pdf/assessment-report/ar5/wg1/WG1AR5_TS_FINAL. pdf (accessed on 25 April 2018). 
12. Garay, J.E.; Chiriboga, D.E. A paradigm shift for socioeconomic justice and health: From focusing on inequalities to aiming at sustainable equity. Public Health 2017, 149, 149-158. [CrossRef] [PubMed]

13. Benson, M.H.; Craig, R.K. The End of Sustainability. Soc. Nat. Resour. 2014, 27, 777-782. [CrossRef]

14. Lara, A.P.; Da Costa, E.M.; Furlani, T.Z.; Yigitcanlar, T. Smartness that matters: Towards a comprehensive and human-centred characterisation of smart cities. J. Open Innov. Technol. Mark. Complex. 2016, 2, 8. [CrossRef]

15. Bachman, L.R. Architecture and the four encounters with complexity. Archit. Eng. Des. Manag. 2008, 4, 15-30. [CrossRef]

16. Kibert, C.J. Establishing Principles and a Model for Sustainable Construction. In Sustainable Construction, Proceedings of the First International Conference of CIB TG 16, November 6-9, 1994, Tampa, Florida, U.S.A.; Kibert, C.J., Ed.; Center for Construction and Environment, M.E. Rinker Sr. School of Building Construction, College of Architecure, University of Florida: Gainesville, FL, USA, 1994; pp. 3-12.

17. CIB Working Commission 82 "Future Studies in Construction". Sustainable Development and the Future of Construction. CIB Report 225. 1998. Available online: http:/ / www.irbnet.de/daten/iconda/CIB13508.pdf (accessed on 25 April 2018).

18. Kemp, R.; Loorbach, D. Governance for Sustainability through Transition Management. Paper for Open Meeting of the Human Dimensions of Global Environmental Change Research Community, Montreal, QC, Canada, 16-19 October 2003. Available online: http://sedac.ciesin.columbia.edu/openmtg/docs/kemp.pdf (accessed on 25 April 2018).

19. Langston, C.A.; Ding, G.K.C. Sustainable Practices in the Built Environment, 2nd ed.; Butterworth-Heinemann: Oxford, MA, USA, 2001; pp. 13-16, ISBN 0-7506-5153-9.

20. Conte, E. Buildings and regenerative thinking: A forward perspective for sustainability. In Progress(es), Theories and Practices, Proceedings of the 3rd International Multidisciplinary Congress on Proportion Harmonies Identities, Bari, Italy, 4-7 October 2017; Kong, M.S.M., Monteiro, M.d.R., Eds.; CRC Press/Balkema, Taylor and Francis Group: Boka Raton, FL, USA, 2018; pp. 89-94, ISBN 978-0-8153-7415-2.

21. Dodge Data \& Analytics. World Green Building Trends 2016: Developing Markets Accelerate Global Green Growth. 2016. Available online: http:/ / fidic.org/sites/default/files/World\%20Green\%20Building\% 20Trends\%202016\%20SmartMarket\%20Report\%20FINAL.pdf (accessed on 25 April 2018).

22. Morata, F.; Sandoval, I.S. When 'green' is not always sustainable: The inconvenient truth of the EU energy policy. Carbon Manag. 2013, 4, 555-563. [CrossRef]

23. Meadows, D.H.; Meadows, D.L.; Randers, J.; Behrens, W.W., III. The Limits to Growth: A Report for the Club of Rome's Project on the Predicament of Mankind; Universe Books: New York, NY, USA, 1972; ISBN 0-8766-3165-0.

24. Gardner, T. Limits to Growth?-A Perspective on the Perpetual Debate. Environ. Sci. 2004, 1, 121-138. [CrossRef]

25. Slaughter, R.A. Why we should care for future generations now. Futures 1994, 26, 1077-1085. [CrossRef]

26. Du Plessis, C. Going Beyond Sustainability: Changing Views, Changing Ways. In Future Challenges in Evaluating and Managing Sustainable Development in the Built Environment; Brandon, P.S., Lombardi, P., Shen, G.Q., Eds.; Wiley-Blackwell: Chichester, UK, 2017; pp. 40-54, ISBN 978-1-119-19071-4.

27. Guy, S.; Farmer, G. Reinterpreting Sustainable Architecture: The Place of Technology. J. Archit. Educ. 2001, 54, 140-148. [CrossRef]

28. Manschot, H.; Suransky, C. From a human centered to a life centered Humanism: Three dimensions of an ecological turn. In Everyday Humanism; McGowan, D., Pinn, A., Eds.; Equinox Publishing Ltd.: Sheffield, UK, 2014; pp. 125-137, ISBN 978-1-7817-9044-1.

29. Blowers, A.; Boersema, J.; Martin, A. Is sustainable development sustainable? J. Integr. Environ. Sci. 2012, 9, 1-8. [CrossRef]

30. Conte, E. Sustainability and Cultural Capital: An Opportunity to Improve the Built Environment. Eur. J. Sustain. Dev. 2017, 6, 235-245. [CrossRef]

31. Dreyfus, D.A.; Grundy, R.D. Influence of the Energy Crisis upon the Future of Environmental Policy. Boston Coll. Environ. Aff. Law Rev. 1974, 3, 252-274.

32. Rosenfeld, A.H.; Hafemeister, D. Energy-Efficient Buildings. Sci. Am. 1988, 258, 78-87. [CrossRef]

33. Chorier, J.; Abele, C.; Hans, J.; Bazzana, M. Moisture Risks Assessment Related to Energy Retrofitting of Existing Buildings: Method and Case Studies. In Proceedings of the XII DBMC International Conference on Durability of Building Materials and Components, Porto, Portugal, 12-15 April 2011. Available online: http:/ / www.irbnet.de/daten/iconda/CIB22403.pdf (accessed on 25 April 2018). 
34. Kramers, A.; Svane, Ö. ICT Applications for Energy Efficiency in Buildings; Report from the KTH Centre for Sustainable Communications; KTH: Stockholm, Sweden, 2011. Available online: http:/ / www.diva-portal. org/smash/get/diva2:492659/fulltext01.pdf (accessed on 25 April 2018).

35. Khasreen, M.M.; Banfill, P.F.G.; Menzies, G.F. Life-Cycle Assessment and the Environmental Impact of Buildings: A Review. Sustainability 2009, 1, 674-701. [CrossRef]

36. Rønning, A.; Brekke, A. Life cycle assessment (LCA) of the building sector: Strengths and weaknesses. In Eco-Efficient Construction and Building Materials Life Cycle Assessment (LCA), Eco-Labelling and Case Studies; Pacheco-Torgal, F., Cabeza, L., Labrincha, J., De Magalhaes, A., Eds.; Woodhead Publishing: Cambridge, UK, 2014; pp. 63-83, ISBN 978-0-85709-767-5.

37. Blengini, G.A.; Di Carlo, T. The changing role of life cycle phases, subsystems and materials in the LCA of low energy buildings. Energy Build. 2010, 42, 869-880. [CrossRef]

38. Papadopoulos, A.M.; Giama, E. Environmental performance evaluation of thermal insulation materials and its impact on the building. Build. Environ. 2007, 42, 2178-2187. [CrossRef]

39. Kozlovská, M.; Spišáková, M. Contruction waste generation across construction project life-cycle. Organ. Technol. Manag. Constr. Int. J. 2013, 5, 687-695. [CrossRef]

40. EU. First European Climate Change Programme. 2000. Available online: https://ec.europa.eu/clima/ policies/eccp/first_en (accessed on 25 April 2018).

41. EU. Directive 2002/91/EC of the European Parliament and of the Council of 16 December 2002 on the Energy Performance of Buildings. Available online: https:/ / eur-lex.europa.eu/legal-content/EN/TXT/PDF/?uri= CELEX:32002L0091\&from=EN (accessed on 25 April 2018).

42. EU. Directive 2010/31/EU of the European Parliament and of the Council of 19 May 2010 on the Energy Performance of Buildings (Recast). Available online: https://eur-lex.europa.eu/legal-content/EN/TXT/ PDF/?uri=CELEX:32010L0031\&from=EN (accessed on 25 April 2018).

43. EU. Directive 2012/27/EU of the European Parliament and of the Council of 25 October 2012 on Energy Efficiency, Amending Directives 2009/125/EC and 2010/30/EU and Repealing Directives 2004/8/EC and 2006/32/EC. Available online: https:/ / eur-lex.europa.eu/legal-content/EN/TXT/PDF/?uri=CELEX: 32012L0027\&from =EN (accessed on 25 April 2018).

44. BRE. Available online: https:// www.breeam.com/ (accessed on 25 April 2018).

45. USGB. Available online: https://new.usgbc.org/leed (accessed on 25 April 2018).

46. Boonstra, C.; Rovers, R.; Pauwels, S. (Eds.) Proceedings of the International Conference Sustainable Building, Maastricht, The Netherlands, 22-25 October 2000. Available online: http:/ / www.irbnet.de/daten/iconda/ CIB2827.pdf (accessed on 25 April 2018).

47. Larsson, N. Overview of the SBE Series. 2017. Available online: http://www.sbe-series.org/the-sbe-series / overview / (accessed on 25 April 2018).

48. IISBE. Available online: http:/ / www.iisbe.org/sbmethod (accessed on 25 April 2018).

49. Reed, R.; Bilos, A.; Wilkinson, S.; Schulte, K.-W. International Comparison of Sustainable Rating Tools. JOSRE 2009, 1, 1-22.

50. EU. Communication from the Commission to the European Parliament, the Council, the European Economic and Social Committee and the Committee of the Regions. A Policy Framework for Climate and Energy in the Period from 2020 to 2030. Available online: https:/ / eur-lex.europa.eu/legal-content/EN/TXT/PDF/ ?uri=CELEX:52014DC0015\&from=EN (accessed on 25 April 2018).

51. EU. Communication from the Commission to the European Parliament, the Council, the European Economic and Social Committee and the Committee of the Regions. Energy Roadmap 2050. Available online: https: / / eur-lex.europa.eu/legal-content/EN/TXT/PDF/?uri=CELEX:52011DC0885\&from=EN (accessed on 25 April 2018).

52. Meacham, B.; Bowen, R.; Traw, J.; Moore, A. Performance-based building regulation: Current situation and future needs. Build. Res. Inf. 2005, 33, 91-106. [CrossRef]

53. Gündeş, S.; Yildirim, S.U. The use of incentives in fostering green buildings. METU J. Fac. Archit. 2015, 32, 45-59. [CrossRef]

54. Conte, E.; Monno, V. Beyond the Buildingcentric Approach: A Vision for an Integrated Evaluation of Sustainable Buildings. Environ. Impact Assess. Rev. 2012, 34, 31-40. [CrossRef]

55. Meir, I.A.; Garb, Y.; Jiao, D.; Cicelsky, A. Post-Occupancy Evaluation: An Inevitable Step toward Sustainability. Adv. Build. Energy Res. 2009, 3, 189-219. [CrossRef] 
56. Rees, W.E. The ecological crisis and self-delusion: Implications for the building sector. Build. Res. Inf. 2009, 37, 300-311. [CrossRef]

57. Leman Stefanovic, I. In Search of the Natural City. In The Natural City. Re-Envisioning the Built Environment; Leman Stefanovic, I., Scharper, S.B., Eds.; University of Toronto Press: Toronto, ON, Canada, 2012; pp. 11-35, ISBN 978-1-4426-1102-3.

58. Jenkin, S.; Pedersen Zari, M. Rethinking Our Built Environments: Towards a Sustainable Future; Research Document; Ministry for the Environment, New Zealand Government: Wellington, New Zealand, 2009. Available online: https://www.scribd.com/document/313383169/Rethinking-Our-Built-Environment (accessed on 25 April 2018).

59. Conte, E. Sustainability and built environment: The role of higher education in architecture and building engineering. Eur. J. Sustain. Dev. 2016, 5, 1-9. [CrossRef]

60. Reed, B. Shifting from 'sustainability' to regeneration. Build. Res. Inf. 2007, 35, 674-680. [CrossRef]

61. Du Plessis, C. Towards a regenerative paradigm for the built environment. Build. Res. Inf. 2012, 40, 7-22. [CrossRef]

62. Cole, R.J.; Oliver, A.; Robinson, J. Regenerative design, socio-ecological systems and co-evolution. Build. Res. Inf. 2013, 41, 37-47. [CrossRef]

63. Lansu, A.; Boon, J.; Sloep, P.B.; van Dam-Mieras, R. Changing professional demands in sustainable regional development: A curriculum design process to meet transboundary competence. J. Clean. Prod. 2013, 49, 123-133. [CrossRef]

64. Mang, P.; Reed, B. Designing from place: A regenerative framework and methodology. Build. Res. Inf. 2012, 40, 23-38. [CrossRef]

65. Conte, E.; Monno, V. The regenerative approach to model an integrated urban-building evaluation method. Int. J. Sustain. Built Environ. 2016, 5, 12-22. [CrossRef]

66. UNESCO. Shaping the Education of Tomorrow: 2012 Report on the UN Decade of Education for Sustainable Development, Abridged. 2012. Available online: https://sustainabledevelopment.un.org/content/ documents/919unesco1.pdf (accessed on 25 April 2018).

67. Orr, D.W. The Nature of Design: Ecology, Culture and Human Intention; Oxford University Press: New York, NY, USA, 2002; pp. 127-134, ISBN 0-19-514855-X.

68. Altomonte, S. Environmental Education for Sustainable Architecture. Rev. Eur. Stud. 2009, 1, 12-21. [CrossRef]

69. Berardi, U. Sustainability assessments of buildings, communities, and cities. In Assessing and Measuring Environmental Impact and Sustainability; Klemeš, J.J., Ed.; Butterworth-Heinemann: Waltham, MA, USA, 2015; pp. 497-545, ISBN 978-0-12-799968-5.

70. Burns, T.R. The Sustainability Revolution: A Societal Paradigm Shift. Sustainability 2012, 4, 1118-1134. [CrossRef]

71. Rees, W.E. Sustainability vs. Resilience. 2014. Available online: http://www.resilience.org/stories/2014-0716/sustainability-vs-resilience/ (accessed on 25 April 2018).

72. Robinson, J.; Cole, R.J. Theoretical underpinning of regenerative sustainability. Build. Res. Inf. 2015, 43, 133-143. [CrossRef]

73. Gibberd, J. Sustainable Resilience or Resilient Sustainability? Available online: https://www.academia.edu/ 4274956/Sustainable_Resilience_or_Resilient_Sustainability (accessed on 25 April 2018).

74. Ahvenniemi, H.; Huovila, A.; Pinto-Seppä, I.; Airaksinen, M. What are the differences between sustainable and smart cities? Cities 2017, 60, 234-245. [CrossRef]

75. UN. Transforming Our World: The 2030 Agenda for Sustainable Development. 2015. Available online: https:/ / sustainabledevelopment.un.org/content/documents/21252030\%20Agenda\%20for\% 20Sustainable\%20Development\%20web.pdf (accessed on 25 April 2018).

(C) 2018 by the author. Licensee MDPI, Basel, Switzerland. This article is an open access article distributed under the terms and conditions of the Creative Commons Attribution (CC BY) license (http:/ / creativecommons.org/licenses/by/4.0/). 